\title{
Excessive production of parathyroid hormone in association with left ventricular dysfunction in regular hemodialysis patients
}

\author{
Hamid Nasri*
}

$\mathrm{P}$ arathyroid hormone (parathormone) is a main regulator of calcium and is a principal regulator of bone and mineral homeostasis (1). Heart and vessel disease starts early during the progression of chronic renal failure and is the mainly common cause of death in these individuals (1). Parathyroid hormone is a polypeptide containing 84 amino acids secreted by parathyroid glands $(1,2)$. Mechanisms of extension of heart and vessel disease are ill-understood. However, dysregulated homeostasis of parathyroid hormone, vitamin $\mathrm{D}$, calcium and phosphorus are responsible partly in cardiac dysfunction in chronic renal failure patients (2-4). Secretion of parathormone is moderated by alterations in concentration of calcium in the blood. In fact, reduced calcium concentration stimulate PTH secretion by the calcium-sensing receptors located in the parathyroid gland. Parathormone forms a tightly controlled feedback cycle and to response to hypocalcemia, this hormone has various targets to increase serum calcium concentration (35). Parathormone is also a key stimulator of vitamin $D$ production in renal tissue and its major physiologic regulator is circulating ionized calcium. The impact of parathormone on intestinal cells, renal tissue, and also bone leads to maintain serum calcium levels within a narrow range. However, elevated levels of parathyroid hormone have been correlated with increased risks of congestive heart failure, cardiovascular mortality hypertension and hypertrophy of left ventricle (1-4). Indeed, disturbed arterial function due to endothelia cell dysfunction is responsible for the above mentioned organ dysfunctions. Thus, cardiac tissue is one of the target organs of parathyroid hormone. Parathormone has a direct hypertrophic property on heart myocytes. Parathyroid hormone has a direct effect on cardiomyocytes, to activate protein kinase $\mathrm{C}$ that further stimulates hypertrophic growth and re-expression of fetal type proteins in heart tissue. Parathyroid hormone is also a potent activator of protein kinase A (6-9). The hypertrophic effect of parathyroid hormone on cardiac cells also is detected by a close association between parathormone levels and proportion of left ventricular mass (5-9). To find the relationship of parathyroid hormone with left ventricular function and structure in hemodialysis (HD) patients, we conducted a study on $73 \mathrm{HD}$ patients. The age of individuals was $46.5 \pm 16$ years. The length of time individuals had been on HD was $21.5 \pm 23.5$ months. We found a significant inverse association of serum alkaline phosphatase with proportion of left ventricular ejection fraction. We also detected a significant inverse association between serum intact parathyroid hormone with proportion of left ventricular ejection fraction in non-

\begin{abstract}
Implication for health policy/practice/research/medical education

Inappropriate parathyroid hormone secretion is intensely associated with establishment and progression of cardiac diseases in hemodialysis patients. Thus attentions should be toward the control of excessive parathormone and management of chronic kidney disease-mineral bone disorder.

Keywords: Parathyroid hormone, Parathormone, Chronic renal failure, Vitamin D, Left ventricular mass, Hypertension, Left ventricular hypertrophy, Left ventricular ejection fraction, Cardiovascular disease
\end{abstract}

diabetic HD patients. In this study we concluded, the role of parathyroid hormone overproduction in the development of left ventricular hypertrophy and low left ventricular ejection fraction (10). Accordingly to find the association of parathyroid hormone with intensity of hypertension in HD patients, we conducted another study on $73 \mathrm{HD}$ patients. The mean duration of HD was $21.5 \pm 23.5$ months. We found a significant positive correlation of hypertension with serum parathormone values $(\mathrm{r}$ $=0.200, P=0.045$ ). Additionally, a significant positive correlation of hypertension with calcium-phosphorus product $(\mathrm{r}=0.231$, $P=0.027$ ) was detected (11). In another study on 102 individuals on regular HD, we detected a significant positive association of pulmonary artery pressure with proportion $(P=0.001)$ and duration of HD $(P<0.001)$. Additionally we found a significant positive association of pulmonary artery systolic pressure (PAP) with serum intact parathyroid hormone in our HD patients. In this study, the duration of dialysis was $17.8 \pm 29$ months and the mean of intact PTH was $338 \pm 306 \mathrm{pg} / \mathrm{mL}$. The mean of PAP was $41.5 \pm 12.6 \mathrm{~mm} \mathrm{Hg}$ (12). Hence, inappropriate PTH secretion is intensely associated with development and progression of cardiac disease in HD patients. Thus attentions should be toward the control of excessive parathormone and management of chronic kidney disease-mineral bone disorder.

Authors' contribution

$\mathrm{HN}$ was the single author of manuscript.

Conflicts of interest

$\mathrm{HN}$ is the current staff of the journal. The peer-review process of the current article has been performed in accordance with the 
COPE guidelines.

Ethical consideration

Ethical issues (including plagiarism, data fabrication, double publication) have been completely observed by the author.

Funding/Support

None.

\section{References}

1. Bacchetta J, Jolivot A, Souberbielle JC, Charrié A, Guebre F, Chauvet $\mathrm{C}$, et al. Parathormone and chronic kidney disease. Nephrol Ther. 2007;3:133-8.

2. Palmer SC, Teixeira-Pinto A, Saglimbene V, Craig JC, Macaskill P, Tonelli M, et al. Association of drug effects on serum parathyroid hormone, phosphorus, and calcium levels with mortality in CKD: a meta-analysis. Am J Kidney Dis. 2015;66:962-71. doi: 10.1053/j.ajkd.2015.03.036.

3. Dusso A, González EA, Martin KJ. Vitamin D in chronic kidney disease. Best Pract Res Clin Endocrinol Metab. 2011;25:647-55. doi: 10.1016/j.beem.2011.05.005.

4. Evenepoel P, Rodriguez M, Ketteler M. Laboratory abnormalities in CKD-MBD: markers, predictors, or mediators of disease? Semin Nephrol. 2014;34(2):151-63. doi: 10.1016/j.semnephrol.2014.02.007.

5. Ketteler M, Block GA, Evenepoel P, Fukagawa M, Herzog CA, McCann L, et al. Executive summary of the 2017 KDIGO Chronic Kidney Disease-Mineral and Bone
Disorder (CKD-MBD) Guideline Update: what's changed and why it matters. Kidney Int. 2017;92:26-36. doi. org/10.1016/j.kint.2017.04.006

6. van Ballegooijen AJ, Rhee EP, Elmariah S, de Boer IH, Kestenbaum B. renal clearance of mineral metabolism biomarkers. J Am Soc Nephrol. 2016;27:392-7. doi: 10.1681/ ASN.2014121253.

7. Khundmiri SJ, Murray RD, Lederer E. PTH and vitamin D. Compr Physiol. 2016;6:561-601. doi: 10.1002/cphy. c140071.

8. Gruson D, Buglioni A, Burnett JC Jr. PTH: Potential role in management of heart failure. Clin Chim Acta. 2014;433:290-6. doi: 10.1016/j.cca.2014.03.029.

9. Silver J, Rodriguez M, Slatopolsky E. FGF23 and PTH-double agents at the heart of CKD. Nephrol Dial Transplant. 2012;27:1715-20. doi: 10.1093/ndt/gfs050.

10. Nasri H, Baradaran A, Naderi AS. Close association between parathyroid hormone and left ventricular function and structure in end-stage renal failure patients under maintenance hemodialysis. Acta Med Austriaca. 2004;31:67-72.

11. Baradaran A, Nasri H. Correlation of serum parathormone with hypertension in chronic renal failure patients treated with hemodialysis. Saudi J Kidney Dis Transpl. 2005;16:28892 .

12. Nasri H. Pulmonary artery pressure in association with serum parathormone in maintenance hemodialysis patients. Arch Med Sci. 2006;2:32-5.

Please cite this paper as: Nasri H. Excessive production of parathyroid hormone in association with left ventricular dysfunction in regular hemodialysis patients. J Parathyr Dis. 2018;6(1):3-4. doi: 10.15171/jpd.2018.02.

Copyright (c) 2018 The Author(s); Published by Nickan Research Institute. This is an open-access article distributed under the terms of the Creative Commons Attribution License (http://creativecommons.org/licenses/by/4.0), which permits unrestricted use, distribution, and reproduction in any medium, provided the original work is properly cited. 